\title{
Problems Faced by the Bitter Gourd Growers in Adoption of Recommended Bitter Gourd Production Technology
}

\author{
K. D. Tankodara ${ }^{1 *}$, M. K. Choudhary ${ }^{2}$, P. K. Sharma ${ }^{2}$ and K. A. Prajapati ${ }^{3}$ \\ ${ }^{1}$ Department of Extension Education, ${ }^{2}$ Department of Horticulture, \\ ${ }^{3}$ Department of Animal Science, Krishi Vigyan Kendra- Kheda, Gujarat, India \\ *Corresponding author
}

\section{A B S T R A C T}

\section{Keywords}

Bitter gourd growers, Bitter gourd production technology, Adoption, Problems

Article Info

\section{Accepted:}

20 January 2021

Available Online:

10 February 2021
Bitter gourd is one of the most important vegetable crops due to its health related and economic importance. Due to consider the fact that farmers face certain problems at their level while adopting and utilizing any production technology, such study was conducted with the objective of find out and study the problems faced by bitter gourd growers in adoption of recommended production technology in Kheda taluka of Kheda district of Gujarat. The study was conducted through ex-post facto research design with multi stage, purposive and random sampling procedures. Mean score was calculated for each problem statement and then ranks were assigned according to their mean scores. The problems were categorized under the title of input related, finance, market related, technical and others. In this investigation, it was observed that majority of the bitter gourd growers faced the problems about high cost of inputs, lack of financial agencies, unavailability of credit at marginal interest, lack of knowledge about export quality produce, high fluctuation in market prices and malpractices of merchants in the markets.

\section{Introduction}

Just like agriculture sector, horticulture sector also contributes major role for the development of nation and nation's economy. In the process of development of horticulture sector, new technologies can be considered as the prime mover. But the benefits of such new improved and recommend technologies are actually derived only when it is efficiently utilized by the individual horticulture farmers in their local situations. But only a small percentage of new technologies have been adopted by them. As a result of that, wide gap between existing yield and potential yield is generally observed. Bitter gourd is an 
important and unique vegetable crop because of its health related and economic importance. Most of the plant parts of bitter gourd like seeds, leaves and fruits are having with multifarious health benefits and work as antidiabetic, anti-obesity, anti-tumor, anti-fungal, anti-HIV, and anti-bacterial qualities.

Due to its unavoidable and multipurpose properties, it is expected that farmers adopt the improved recommended production technology with a view to increase the production, productivity and yield.

In the process of adoption of any new or recommended technologies, it is generally observed that farmers face certain problems on their level.

With a view to consider this fact and seeing the importance of such vegetable crop, a study was carried out to know the problems or constraints faced by the bitter gourd growers in adoption of recommended bitter gourd production technology.

The main objectives of this study include to study the problems faced by the bitter gourd growers in adoption of recommended bitter gourd production technology

\section{Materials and Methods}

Ex-post facto research design was selected for the research study. The study was conducted in Kheda district of Gujarat state. Kheda district is one of the leading bitter gourd growing districts of middle Gujarat Agroclimatic zone of Gujarat State. Kheda taluka of Kheda district was selected purposively as the area under the cultivation of bitter gourd is higher in this taluka. Ten villages (Hariyala, Gandhipura, Betadi lat, Jesvapura, Vasana Khurd, Khumarvad, Parsantaj, Dedarda, Shokhada Bhatha, Chhaganpura) were selected from the taluka. From each selected village, 10 Bitter gourd growers were selected randomly. Thus, total 100 bitter gourd growers were selected for the study.

The data regarding various kinds of constraints i.e. input related constraints, financial, marketing, technical and other constraints were collected with the help of well structured, pre-tested schedule through personal contact.

The bitter gourd growers were asked to give their responses regarding the problems on 3 point rating scale where 2,1 and 0 score were assigned to each problem where 2 score for mostly face, 1 score for less face, and 0 for not face that problem.

On that basis, mean scores were calculated for individual problem statement. Overall ranks were assigned on the basis of mean scores. Similar procedures were also followed by Markana et al., (2015), Raviya (2017) and Tankodara et al., (2020) for getting appropriate conclusion.

\section{Results and Discussion}

The results in table 1 indicate the problems faced by the bitter gourd growers in adoption of recommended bitter gourd production technology.

On the basis of the table 1, it can be seen that that major problems faced by the bitter gourd growers were; high cost of inputs, lack of financial agencies, unavailability of credit at marginal interest and lack of knowledge about export quality produce (2.00 mean score) and they got rank $1^{\text {st }}$, followed by high fluctuation in market prices (1.92 mean score), malpractices of merchants in the markets (1.90 mean score), cloudy weather at the time of flowering/fruiting stage (1.82 mean score) which got rank $2^{\text {nd }}, 3^{\text {rd }}$ and $4^{\text {th }}$, respectively. Other problems faced by the bitter gourd 
growers from rank $5^{\text {th }}$ to $16^{\text {th }}$ were; more labor requirement (1.80 mean score), lack of proper marketing facilities (1.78 mean score), unavailability of inputs in time (1.74 mean score), unavailability of labors (1.70 mean score), high/low temperature during sowing period (1.68 mean score), unavailability of suitable equipment for weeding (1.66 mean score), unavailability of recommended chemicals (1.62 mean score), lack of skill for seed and soil treatment (1.50 mean score), unavailability of improved varieties (1.46 mean score), more requirement of fertilizers and manures (1.34 mean score), lack of knowledge and skill about weed management (1.34 mean score), high charges of electricity (0.40 mean score) and timely unavailable electricity (0.36 mean score), respectively.

On the basis of above mentioned finding, it can be concluded that majority of bitter gourd growers faced the problems of high cost of inputs, lack of financial agencies, unavailability of credit at marginal interest, lack of knowledge about export quality produce, high fluctuation in market prices and malpractices of merchants in the markets. While the problems like more requirement of fertilizers and manures, lack of knowledge and skill about weed management, high charges of electricity and timely unavailable electricity were faced by less number of bitter gourd growers.

Table.1 Problems faced by the bitter gourd growers in adoption of recommended bitter gourd production technology

\begin{tabular}{|l|l|l|l|}
\hline $\begin{array}{l}\text { Sr. } \\
\text { No. }\end{array}$ & Impediments & Mean Score & Rank \\
\hline A. & Input related problems & 1.46 & \\
\hline 1. & Unavailability of improved varieties & 1.34 & XIII \\
\hline 2. & More requirement of fertilizers and manures & 1.62 & XIV \\
\hline 3. & Unavailability of recommended chemicals & 1.74 & VII \\
\hline 4. & Unavailability of inputs in time & 1.70 & VIII \\
\hline 5. & Unavailability of labors & & \\
\hline B. & Financial problems & 2.00 & I \\
\hline 6. & High cost of inputs & 0.40 & XV \\
\hline 7. & High charges of electricity & 2.00 & I \\
\hline 8. & Lack of financial agencies & 2.00 & I \\
\hline 9. & Unavailability of credit at marginal interest & \\
\hline C. & Marketing related problems & 1.78 & VI \\
\hline 10. & Lack of proper marketing facilities & 1.90 & III \\
\hline 11. & Malpractices of merchants in the markets & 1.92 & II \\
\hline 12. & High fluctuation in market prices & & \\
\hline D. & Technical problems & 1.50 & XII \\
\hline 13. & Lack of skill for seed and soil treatment & 1.34 & XIV \\
\hline 14. & Lack of knowledge and skill about weed management & I \\
\hline 15. & Lack of knowledge about export quality produce & 2.00 & \\
\hline E. & Other problems & & IX \\
\hline 16. & High/low temperature during sowing period & 1.68 & XVI \\
\hline 17. & Timely unavailable electricity & 0.36 & X \\
\hline 18. & Unavailability of suitable equipment for weeding & 1.66 & IV \\
\hline 19. & Cloudy weather at the time of flowering/fruiting stage & 1.82 & V \\
\hline 20. & More labor requirement & 1.80 & \\
\hline & & & \\
\hline
\end{tabular}




\section{Implication}

The study will serve as a guideline for the planners and extension agencies for planning and implementing various polices on such vegetable crop as well as other horticulture crops' production in that area.

This study will work as a review for various researchers and will enlighten their path in doing similar kind of works.

\section{References}

Markana JG, Kalsariya BN, Bharad ND. Constraints faced by farmers in adoption of scientific kharif groundnut production technologies. Gujarat Journal of Extension Education. 2015; 26(1):43-46.

Raviya PB. Knowledge and adoption of farmers about cotton production practices recommended by GAU and JAU in Junagadh district. M.Sc. (Agri). Thesis (Unpublished). J.A.U., Junagadh, 2017.

Tankodara KD, Gohil GR, Khunt KR. Problems faced by the chickpea growers in adoption of recommended chickpea production technology. Journal of Pharmacognosy and Phytochemistry. 2020; 9(2):388-389.

\section{How to cite this article:}

Tankodara, K. D., M. K. Choudhary, P. K. Sharma and Prajapati, K. A. 2021. Problems Faced by the Bitter Gourd Growers in Adoption of Recommended Bitter Gourd Production Technology. Int.J.Curr.Microbiol.App.Sci. 10(02): 2667-2670.

doi: https://doi.org/10.20546/ijcmas.2021.1002.292 